\title{
Validation of a brief version of the Inventory of Life Factors Interfering Grief and Complicated Grief (ILFIGv2)
}

\author{
Marta Villacieros ${ }^{1, *}$, Patricia Sánchez ${ }^{2}$, Jose-Carlos Bermejo ${ }^{1}$, Marisa Magaña ${ }^{1}$, and Valentín Rodil ${ }^{1}$
}

1 Centro de Humanización de la Salud. Centro San Camilo. Madrid (Spain).

2 Facultad de Psicologia. Universidad Autónoma de Madrid (Spain).

Título: Validación de una versión breve del Inventario de Factores Vitales que Interfieren en el Duelo y Duelo Complicado (IFVIDv2).

Resumen: Existen algunas circunstancias vitales que pueden interferir en el proceso de duelo normal. El Inventario de Factores Vitales que Interfieren en el Duelo y Duelo Complicado (IFVID) se publicó por primera vez, con el fin de identificar estos factores, en 2017. El presente estudio tiene como objetivo validar una versión breve del cuestionario, el IFVIDv2. En esta segunda versión, las seis dimensiones del cuestionario (Culpa, Herencia, Economía, Sexualidad, Inmortalidad y Sensación de presencia) se ocultaron, y se redujeron a 24 el número de ítems. Con una muestra total de 248 encuestados, se contrastó una estructura de seis factores mediante análisis factorial confirmatorio. El modelo resultante obtuvo índices de ajuste razonables: $\chi^{2}(237)=383.409, p<.001 ; C F I=0.984, T L I=0.981$ RMSE $A=0.050,95 \%$ CI $[0.041-0.059]$, aportando pruebas de validez basadas en la estructura interna del inventario. También se obtuvieron pruebas de validez basadas en la relación con otras variables por asociación con un criterio externo. En cuanto a la fiabilidad, todas las subescalas del IFVIDv2 obtuvieron coeficientes alfa de Cronbach y omega por encima de .70 y .80 , respectivamente. Se ha validado una versión breve de IFVID, que constituye un instrumento con posibilidad de prevenir y evitar el prolongamiento del duelo, ya que es capaz de detectar aspectos no expresados que, según los dolientes, necesitan atención.

Palabras clave: Factores vitales. Duelo complicado. Luto. Instrumentos de medida. Estudio de validación de cuestionario.

\section{Introduction}

Grieving is a natural, psychological process which occurs after the loss of a loved one (Barreto et al., 2008; Burke \& Neimeyer, 2012). Even though most people overcome, more or less, a grieving process in a relatively short period of time, there are some factors or situations that can alter this process, increasing either the intensity or the duration of the suffering (Barreto et al., 2012). Several risk factors that may lead to the development of complicated grief have been widely described (Barreto et al., 2008; Burke \& Neimeyer, 2012; Field \& Filanosky, 2009), such as the relationship to the deceased (e.g., ambivalent or dependency relationship), cause of death (e.g., sudden death, death after a long illness), intrapersonal (e.g., guilt, coping strategies, attachment style) or interpersonal factors (e.g., lack of social or family support).

In daily practice, however, some other life circumstances that can interfere with the normal mourning process and prolong it, are found (Bermejo \& Santamaría, 2011). For example, in case of a person that has to deal with the misfor-

* Correspondence address [Dirección para correspondencia]: Marta Villacieros. Centro de Humanización de la Salud. Centro San Camilo. Madrid, (Spain). E-mail: investigacion@humanizar.es

(Article received: 13-02-2020; revised: 15-04-2020; accepted: 22-05-2020)
Abstract: There are some life circumstances that can interfere with a normal mourning process. In order to identify these factors, the Inventory of Life Factors Interfering Grief and Complicated Grief (ILFIG) was first published in 2017. The present study aims to validate a briefer version of the questionnaire, the ILFIGv2. In this second version, the six dimensions of the questionnaire (Guilt, Inheritance, Economy, Sexuality, Immortality and Sense of presence) were hidden, and the items were reduced to 24 . With a total sample of 248 respondents, a six-factor structure was tested. Confirmatory factor analysis model obtained reasonable goodness of fit indices: $\chi^{2}(237)=383.409, p<.001 ; C F I=0.984, T L I=0.981 ; R M S E A=$ $0.050,95 \%$ CI $[0.041-0.059]$, providing validity evidences based on the internal structure of the test. Validity evidences based on the relation with other variables were also provided by external criteria correlation. Regarding reliability, all the subscales of the ILFIGv2 obtained Cronbach's alpha and omega coefficients above .70 and .80 , respectively. A brief version of ILFIG has been validated. It heralds a potential means to prevent and avoid grief lengthening, as it can measure unexpressed aspects which, according to grievers, demand attention.

Keywords: Life factors. Complicated grief. Mourning. Measurement instrument. Questionnaire validation study.

tunes left by the deceased, or inheritance, she/he may experience how much time or energy needed for being aware of the loss could be stolen. The same complication happens with other life factors interfering grief, which are not easily recognized and appear as a disturbance. These factors bring feelings of unease, so the attention they would deserve is very often postponed. Given a complicated grief, these circumstances may exacerbate the anxiety and complicate it further (Bermejo \& Santamaría, 2011).

Some data of prevalence, incidence and interfering intensity of grief process have been described (Bermejo et al., 2016). These authors analyzed several interfering circumstances, which they metaphorically called "fleas", given that fleas are not easily seen, they suck blood and inoculate a kind of saliva that works as an anesthetic, they bring feelings of unease and they itch very much.

Further on, the Inventory of Life Factors Interfering Grief and Complicated Grief (ILFIG; Bermejo et al., 2017) was published. It was drawn from the Humanize Model, a humanistic grief and bereavement intervention model developed by Magaña and Bermejo (2013), which has already been practiced for more than 20 years in a Bereavement Listening Centre. This questionnaire included 30 items, in six common grief circumstances, which are not usually focused when taking action into complicated grief prevention. But for guilt, already included in the Bereavement Risk Index 
(Parkes \& Weiss, 1983), it scored for different and complementary circumstances to other published questionnaires. The six fleas, chosen under the authors' working experience, were: Guilt, describing obsessive self reproves of the grieving after death; Inheritance, describing the interfering effect of familiar relationships deterioration due to inheriting process; Economy, which describes how economic changes after loss impact the grieving; Sexuality, describing interferences due to changes in sexual experiences after loss; Immortality, describing the consequences for the griever of keeping the beloved alive through social networks and web profiles that her or himself was using; and Sense of presence, that describes the shame and vigilance state of the griever due to the feeling of physical presence of the deceased. Validation showed reasonable goodness-of-fit-indices $\left(X^{2}(399)=626.583, p<\right.$ $.001 ;$ RMSE $A=0.051,90 \%$ CI $[0.043-0.058]$; $C F I=$ 0.985; TLI $=0.983$ ) and a high alpha coefficient (.975) (Bermejo et al., 2017). As far as we know, there is no other specific measurement instrument for bereavement situations in which all of them are taken together into account. Furthermore, little specialized literature can be found about them, far less in Spain.

However, this Inventory had some limitations which needed to be solved. It was too long for a griever to fill in, and the six dimensions were presented independently; thus, statistical analyses were conditioned. For this reason, the main objective of this study was to validate a briefer version of the Inventory of Life Factors Interfering Grief and Complicated Grief, ILFIGv2, hiding the 6-dimension structure and reducing it down to 24 items. For testing the validity based on the internal structure of this new shorter version of the Inventory, a Confirmatory factor analysis (CFA) was used. Moreover, validity evidences based on the relation with other variables, such as convergent validity and external criteria validity, were also analyzed.

\section{Method}

\section{Participants}

Two different participant samples were used. All 449 attendees who took part in the Grief Workshops (organized in Madrid and Zamora) by a healthcare center (sited in the Community of Madrid), were invited to take part in the research. The aim of these days is to reflect on strategies of accompaniment and keys to live a healthy grief. Participants are both people who accompany mourning people and people who have or are living it. Final participants were 248 222 of them from the workshop organized in Madrid and 25 from the one organized in Zamora (being the response rate approximately 55\%).

Of them, $208(84 \%)$ were women, with an average age of 47.4 years old $(S D=16)$. Half of the sample had a University profile $(48.4 \%, n=120)$. Almost half of them were married couples and legal partnerships $(43.55 \%, n=108)$, and $56.5 \%$ (140) were single, widowed or divorced.
Almost half of the sample $(45.7 \%, n=113)$ had medium or extensive grief training, while almost the same amount $(46.7 \%, n=116)$ had little or none. It is expected that most participants are somehow related to the centre database, where workshops are published. This centre offers different grief training levels, a master's degree on grief intervention, weekend trainings and day workshops, which may be examples of the few grief training programs which actually exist in Spain. Also, this centre holds the Bereavement Listening Centre, where 150 volunteers accompany grieving processes. For these reasons, participants were characterized around their level of grief training and grief experience.

\section{Instrument}

Apart from sociodemographic variables, such as age (question $\mathrm{Q} 1)$, sex $(\mathrm{Q} 2)$, study level (Q3), grief training (Q4) and civil status (Q5), in order to distinguish people who have not suffered any grief experience from people who have or are still grieving, participants were also requested to define their grieving experience (Q6); "I answer on: my opinion or training basis, as I haven't suffered any grieving experience / on my actual grieving experience situation / on a previous grieving experience / on both, training and grieving experience". In addition, in case of grief experience, participants were asked about their relationship with the deceased (Q7), time from death (Q8), perceived level of grief overcoming (Q9), perceived level of economic (Q10) and legacy (Q11) changes after loss and perceived level of social networks used by the deceased (Q12). And for last, as final question, opinion about the difficulty of a grieving process was requested (from $1=$ nothing to $10=$ a lot).

With the authors' permission, several modifications were done to the published Inventory of Life Factors Interfering Grief and Complicated Grief (ILFIG; Bermejo et al., 2017) (Appendix):

- In order to hide the 6-dimension structure, items were messed up, reenumerated and included under the same header instructions: "Considering the following scale of responses, please answer, which of these experiences occur in bereavement, how often or how much in intensity?" All the items were adapted to an identical five-point response scale $(1=$ Nothing $/$ Never to $5=$ Totally/Always).

- In order to reduce length, the 6 items which obtained the lowest saturation values of each dimension in the CFA conducted in the previous study by Bermejo et al. (2017) were deleted. These were (former numeration) item 4 (saturation value $=0.351), 8$ (0.674), 15 (0.772), 19 (0.702), $21(0.756)$ and $26(0.549)$. The new six dimensions are represented by the indicators of Guilt (actual numeration: items 1, 7, 10 and 20), Inheritance $(6,13,14$ and 18), Economy (3, 16, 19 and 22), Sexuality (4, 12, 15, 17 and 23), Immortality (5, 9 and 21) and Presence (2, 8, 11 and 24). 
- Finally, items were reworded in order to adapt them to be responded by any participant (not only mourning people, also for people who accompany and listen to others' grieving processes).

\section{Procedure}

The questionnaire was handed to all workshop participants inside the documentation pack given out at registration. Participants were asked for their collaboration and to post the completed questionnaires in boxes provided at the registration desk when the workshops finished.

Prior to this, the Healthcare Ethics Committee at the healthcare center reviewed the questionnaire content and the center's management authorized its use during the workshops. In the instructions provided, the anonymity, confidentiality and voluntary nature of the questionnaire were emphasized, together with its objective: to deepen into different aspects that can complicate the grieving process.

\section{Statistical and psychometric analysis}

In order to provide validity evidences based on the internal structure of the ILFIGv2 scale, a confirmatory factor analysis (CFA) was carried out using the Mplus 7.0 software (Muthén \& Muthén, 1998 - 2012). The robust weighted least squares means and variance adjusted (WLSMV) estimation method was used due to the categorical nature of the variables (Abad, Olea, Ponsoda \& García, 2011; Brown, 2006). Polychoric correlation matrix was then used as the imputation matrix. The following goodness of fit indices were considered to assess the quality of the model: $\chi^{2}$ as an absolute fit index, RMSE $A$ as a parsimony fit index, and CFI and TLI as comparative fit indices. An RMSE $A$ of less than .08 (Brown, 2006) was used as an acceptable modelling criteria. Indicators from the Comparative Fit Index (CFI) (Bentler, 1992) and the Non-Normed Fit Index or Tucker-Lewis Index (TLI) were also used, where the model is considered to fit if values over .90 are obtained (Abad et al., 2011; Hu \& Bentler, 1998).

Regarding external criteria validation, it was analyzed by correlating (Pearson coefficient) each of the factors with difficulty of a grieving process opinion scores, taken as an external criteria variable.

Convergent validity was also analyzed through independent sample $T$-tests between the variables "perceived level of economic changes after loss" (Q10) and the Economy factor of the ILFIGv2; "perceived level of legacy changes after loss" (Q11) and the Legacy factor; and "perceived level of social networks use by the deceased" (Q12) and the Immortality factor (after dichotomizing Q10, 11 and 12).

In addition, the reliability was addressed with the Cronbach's alpha (95\% CI) and Omega coefficients.

Finally, comparisons among groups were studied through independent samples $T$-tests (for binary variables) or analyses of variance (for variables with more than two groups).

\section{Results}

\section{Grief training and experience characteristics of the sample}

All but 4 people declared to have had a grief experience. With respect to prior training in grief, almost half of the sample $(49.3 \%, 113)$ had some kind of training, and besides, almost half of the respondents answered from both grief training and experience $(45.2 \%, 112)$.

In addition, most of the participants had lost just one beloved $(73.4 \%, 182)$. Regarding the relationship with the deceased loved one, most of them had lost their parent $(38.3 \%$, $95)$ and grandparent $(27.8 \%, 69)$; and almost half of the participants had lost their beloved more than 5 years ago $(46 \%$, 114). Finally, $90.3 \%$ considered they have, at least fairly, processed their grief (Table 1).

Table 1. Grieving process experience characteristics of the sample.

\begin{tabular}{|c|c|c|c|}
\hline Variable & Category & $n$ & $\%$ \\
\hline \multirow{2}{*}{ Grief training } & No & 116 & 46.8 \\
\hline & Yes & 113 & 45.6 \\
\hline \multirow{4}{*}{ I answer from... } & $\begin{array}{l}\text { My opinion or training, as I have } \\
\text { not suffered grief }\end{array}$ & 4 & 1.6 \\
\hline & My actual grief experience & 27 & 10.9 \\
\hline & A prior grief experience & 99 & 39.9 \\
\hline & $\begin{array}{l}\text { Both, grief training and experi- } \\
\text { ence }\end{array}$ & 112 & 45.2 \\
\hline \multirow{3}{*}{$\begin{array}{l}\text { Number of } \\
\text { deceased }\end{array}$} & None & 3 & 1.2 \\
\hline & One & 182 & 73.4 \\
\hline & More than one & 59 & 23.8 \\
\hline \multirow{8}{*}{$\mathrm{He} /$ she was my } & Couple & 26 & 10.5 \\
\hline & Daughter/son & 15 & 6.0 \\
\hline & Parent & 95 & 38.3 \\
\hline & Grandparent & 69 & 27.8 \\
\hline & Brother/sister & 7 & 2.8 \\
\hline & Other relative & 19 & 7.7 \\
\hline & Friend & 6 & 2.4 \\
\hline & Other & 5 & 2.0 \\
\hline \multirow{4}{*}{ Time from death } & Less than 1.5 years & 43 & 17.3 \\
\hline & $1.5-3$ years & 32 & 12.9 \\
\hline & $3-5$ years & 36 & 14.5 \\
\hline & More than 5 years & 114 & 46.0 \\
\hline \multirow{5}{*}{$\begin{array}{l}\text { The extent to } \\
\text { which you have } \\
\text { processed your } \\
\text { bereavement }\end{array}$} & At all & 3 & 1.2 \\
\hline & Poor & 13 & 5.2 \\
\hline & Fair & 57 & 23.0 \\
\hline & Good & 91 & 36.7 \\
\hline & Excellent & 76 & 30.6 \\
\hline
\end{tabular}

\section{Validity and reliability of the ILFIGv2}

In order to study the validity evidences based on the internal structure of the ILFIGv2, a six-factor structure was tested in relation to the previous scale (Guilt, Inheritance, Economy, Sexuality, Immortality and Sense of presence). 
Figure 1 shows the CFA model standardized results. All the fully-standardized factor loadings were significant $(p<.001)$ and substantive (above .70). In addition, the goodness of fit indices proved the model fit the data reasonably well: $\chi^{2}(237)$
$=383.409, p<.001 ; C F I=0.984, T L I=0.981 ;$ RMSE $A=$ $0.050,95 \%$ CI $[0.041-0.059]$. All factors were positively and significantly correlated.

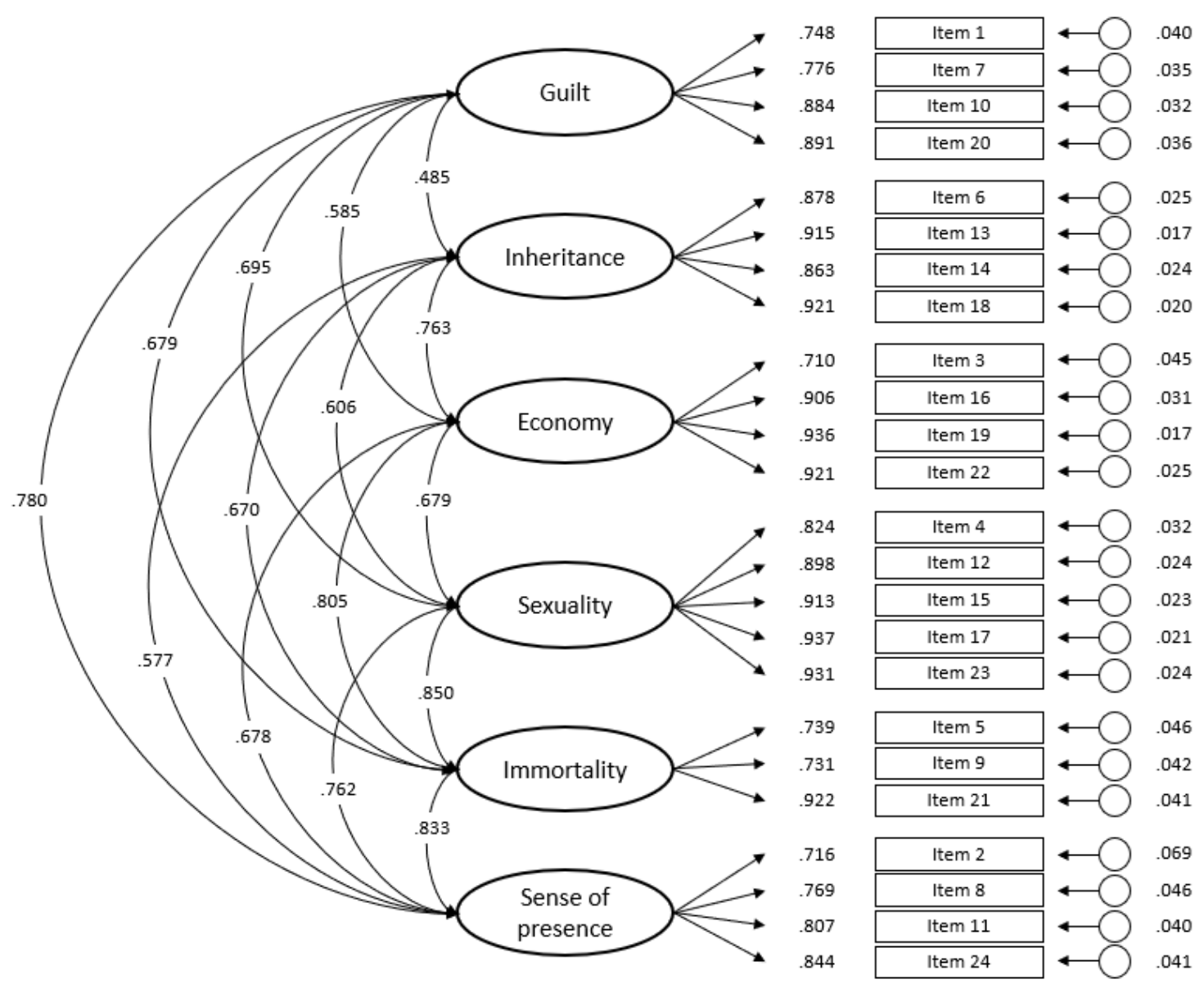

Figure 1. CFA model and standardized results of the ILFIGv2.

Regarding the external criteria validation, table 2 shows Pearson's correlations between the six ILFIGv2 factors and the main external criteria variable (difficulty of a grieving process opinion) scores. All the correlations were statistically significant $(p<.001)$ and positive.

Table 2. Pearson coefficients between the ILFIGv2 factors and external criteria variables.

\begin{tabular}{|c|c|c|c|c|c|c|}
\hline & Gui. & Inh. & Eco. & Sex. & Imm. & Pre. \\
\hline How difficult or complicated do you consider a bereavement process is? & .318 & .236 & .270 & .225 & .295 & .242 \\
\hline
\end{tabular}

In addition, with regard to the convergent validity evidences, people who declared higher levels of legacy changes after loss $(M=2.31 ; S D=1.24)$ scored higher in the Legacy factor of the ILFIGv2 than people with lower levels of perceived legacy changes $(M=1.68$; $S D=0.98)$, being Student`s $T$ statistic $=-4.062 ; p<.001$. Moreover, people who declared higher levels of economic changes after the loss $(M$ $=2.45 ; S D=1.08)$ significantly scored higher in the Economy factor than people who declared lower levels of economic changes $(M=1.38$; $S D=0.71)$, being Student`s $T$ sta- tistic $=-7.523 ; p<.001$. Besides, people with higher levels of perceived social networks use by the deceased $(M=2.31$; $S D$ $=1.02)$ scored higher in the Immortality factor than people with lower levels in this variable $(M=1.43$; $S D=0.74)$, being Student`s T statistic $=-5.013 ; p<.001$.

In relation to the reliability of the subscales of the ILFIGv2, all of them obtained Cronbach's alpha and omega coefficients above .70 and .80 , respectively (Table 3 ). The factors Sexuality and Inheritance showed the highest reliability coefficients. 
Table 3. Alpha (CI) and omega coefficients for the six ILFIGv2 dimensions.

\begin{tabular}{lcccccc}
\hline & Gui. & Inh. & Eco. & Sex. & Imm. \\
\hline Cronbach's $\alpha[\mathrm{CI}]$ & .855 & .904 & .872 & .922 & .730 & .776 \\
Omega & {$[.823-.883]$} & {$[.882-.922]$} & {$[.844-.897]$} & {$[.904-.937]$} & {$[.664-.786]$} & {$[.726-.819]$} \\
\hline
\end{tabular}

Note: Gui $=$ Guilt, Inh $=$ Inheritance, Eco $=$ Economy, Sex $=$ Sexuality, Imm $=$ Immortality, Pre $=$ Sense of presence

\section{Comparisons among groups}

Table 4 shows means and standard deviations of the variables sex, studies, marital status, grief training and grief overcoming. Given that the violation of the assumption of normality doesn't have relevant consequences when the sample size is relatively large (Pardo et al., 2009), T-tests were performed for the different levels of the previously mentioned variables in all ILFIGv2 dimensions. Regarding marital status, single people scored statistically higher in Economy dimension (being Student's $T$ statistic $=2.125 ; p$ $=.035)$. With regard to grief training, people without grief training scored higher in Sense of presence $(T=2.108$; $p=$ .036) than people with grief training. In addition, people who are still grieving scored higher in Guilt $(T=3.447 ; p=.001)$ and Sense of presence $(T=2.519 ; p=.012)$ than those who have already overcome their grieving process.

Table 4. Variables sex, studies, marital status, grief training and grief overcoming. ILFIGv2 dimension means (M), standard deviations (SD) and mean comparisons between groups (Student`s T-test).

\begin{tabular}{|c|c|c|c|c|c|c|}
\hline Category $(n)$ & $\begin{array}{c}\text { Guilt } \\
M(S D)\end{array}$ & $\begin{array}{c}\text { Inheritance } \\
M(S D)\end{array}$ & $\begin{array}{l}\text { Economy } \\
M(S D) \\
\end{array}$ & $\begin{array}{l}\text { Sexuality } \\
M(S D)\end{array}$ & $\begin{array}{c}\text { Immortality } \\
M(S D)\end{array}$ & $\begin{array}{c}\text { Sense of presence } \\
M(S D) \\
\end{array}$ \\
\hline Women $(208)$ & $2.17(1.07)$ & $1.95(1.15)$ & $1.71(0.99)$ & $1.52(0.84)$ & $1.60(0.87)$ & $1.53(0.75)$ \\
\hline $\operatorname{Men}(38)$ & $2.11(1.13)$ & $1.98(1.09)$ & $1.64(0.80)$ & $1.58(0.91)$ & $1.48(0.78)$ & $1.36(0.50)$ \\
\hline University Studies (84) & $2.10(1.05)$ & $1.91(1.07)$ & $1.65(0.88)$ & $1.53(0.84)$ & $1.53(0.82)$ & $1.49(0.71)$ \\
\hline Non-University Studies (164) & $2.30(1.12)$ & $2.03(1.27)$ & $1.77(1.10)$ & $1.54(0.87)$ & $1.68(0.92)$ & $1.55(0.75)$ \\
\hline Single (139) & $2.14(1.03)$ & $2.02(1.13)$ & $1.80^{\mathrm{a}}(0.96)$ & $1.51(0.82)$ & $1.60(0.84)$ & $1.55(0.74)$ \\
\hline In a relationship $(108)$ & $2.19(1.13)$ & $1.85(1.14)$ & $1.54 \mathrm{~b}(0.95)$ & $1.55(0.89)$ & $1.55(0.87)$ & $1.45(0.69)$ \\
\hline Grief training (113) & $2.10(1.01)$ & $2.05(1.17)$ & $1.71(0.96)$ & $1.57(0.92)$ & $1.57(0.87)$ & $1.40^{\mathrm{a}}(0.62)$ \\
\hline No Grief training (116) & $2.22(1.13)$ & $1.91(1.15)$ & $1.70(0.97)$ & $1.50(0.80)$ & $1.61(0.85)$ & $1.60^{\mathrm{b}}(0.78)$ \\
\hline Has overcome grief (223) & $2.07 \mathrm{a}(1.03)$ & $1.91(1.12)$ & $1.65(0.95)$ & $1.48(0.81)$ & $1.53(0.83)$ & $1.46^{a}(0.69)$ \\
\hline Has not overcome grief (16) & $3.00^{\mathrm{b}}(1.21)$ & $1.89(1.02)$ & $2.00(1.03)$ & $1.91(1.12)$ & $1.94(0.85)$ & $1.91^{\mathrm{b}}(0.73)$ \\
\hline
\end{tabular}

Note. The values with different superscript letters (underlined) in a column are significantly different $(p<.05)$.

Finally, regarding the relationship with the deceased (Table 5), grievers who have lost their child scored higher in Guilt than people who have lost their parent or grandparent (being Snedecor F-statistic $=2.159 ; p=.039)$. Also, these grievers scored higher in Sexuality than the ones who have lost their parent $(F=4.047 ; p<.001)$.

Table 5. Relationship with the deceased. ILFIGv2 means (M), standard deviations (SD) and mean comparisons between groups (ANOVA test).

\begin{tabular}{|c|c|c|c|c|c|c|}
\hline Category $(n)$ & $\begin{array}{c}\text { Guilt } \\
M(S D)\end{array}$ & $\begin{array}{c}\text { Inheritance } \\
M(S D)\end{array}$ & $\begin{array}{c}\text { Economy } \\
M(S D)\end{array}$ & $\begin{array}{l}\text { Sexuality } \\
M(S D)\end{array}$ & $\begin{array}{c}\text { Immortality } \\
M(S D)\end{array}$ & $\begin{array}{c}\text { Sense of presence } \\
M(S D)\end{array}$ \\
\hline Couple (26) & $2.13(1.04)$ & $1.54(1.07)$ & $1.72(1.00)$ & $1.57(0.97)$ & $1.59(0.92)$ & $1.41(0.57)$ \\
\hline Child (15) & $2.95^{\mathrm{a}}(1.05)$ & $1.73(1.05)$ & $1.350 .63)$ & $2.23^{\mathrm{b}}(0.80)$ & $1.91(0.86)$ & $1.48(0.44)$ \\
\hline Parent (95) & $2.03^{b}(0.99)$ & $1.79(1.04)$ & $1.64(0.97)$ & $1.25^{\mathrm{a}}(0.49)$ & $1.33(0.65)$ & $1.34(0.52)$ \\
\hline Grandparent (69) & $\underline{1.99 \mathrm{~b}(1.05)}$ & $2.17(1.20)$ & $1.67(0.93)$ & $1.58(0.93)$ & $1.65(0.88)$ & $1.61(0.73)$ \\
\hline Sibling $(7)$ & $2.64(1.01)$ & $1.61(0.73)$ & $1.75(1.33)$ & $1.54(0.87)$ & $1.76(1.10)$ & $1.95(1.35)$ \\
\hline $2^{\text {nd }}$ degree relative (19) & $2.11(0.96)$ & $2.29(1.36)$ & $1.86(1.02)$ & $1.75(1.11)$ & $1.93(0.96)$ & $1.54(0.88)$ \\
\hline Friend $(\sigma)$ & $2.54(1.67)$ & $1.67(0.77)$ & $1.54(0.93)$ & $1.46(0.64)$ & $1.78(1.13)$ & $1.75(1.07)$ \\
\hline Other (4) & $2.63(0.97)$ & $2.53(1.12)$ & $2.50(1.08)$ & $2.30(1.39)$ & $2.08(1.42)$ & $2.13(1.45)$ \\
\hline
\end{tabular}

Note. The values with different superscript letters (underlined) in a column are significantly different $(p<.05)$

Regarding sex, studies and time from death, no differences were found.

\section{Discussion}

The main aim of this research was to validate a brief version of the Inventory of Life Factors Interfering Grief and Com- plicated Grief. The results of this study have confirmed a valid and reliable 24 -item version of the previously published six factor model (Guilt, Inheritance, Economy, Sexuality, Immortality and Sense of presence), being named ILFIGv2.

Given a considerable sample $(n=248)$, mainly experienced on (actual or prior) grief, with for, at least, one deceased beloved, with a wide range of relationships with the deceased (couple, daughter/son, parent, grandparent, broth- 
er/sister, other relative and friend), whom mostly consider they have (at least fairly) finalized their grieving process, evidences for internal structure validity, convergent validity and external criteria validity have been gathered. Structural validity has been proved by the significant and substantive factor loadings of the indicators, all of them above 0.70 , as well as by the goodness-of-fit indices obtained. Content validity has also been proved, as all factors were positively and significantly correlated, in consonance with the fact that in a grief process, when one factor is complicating grief, there is a higher risk of suffering other factors.

Furthermore, associations shown between the six ILFIGv2 factors and the difficulty of a grieving process opinion scores indicate that this questionnaire is taking note of, at least, six potentially factors for complicating grief. At this point, it is important to note that, the higher level of experiencing each of the risk factors (i.e. changes in the family economy after the loss), the higher score is obtained in each of the ILFIGv2 dimensions (i.e. economy).

Moreover, comparisons among groups confer greater validity to the questionnaire. Worden, Aparicio and Barberán (1997) and other experts on grief (Echeburúa \& Herrán, 2007), have described economic precariousness as a risk factor. This is the case not only of single or divorced people who suffer a loss and count only with a single income, but it is also the case of widows/widowers when losing a couple, who go on from a double to a single income or just remain with a retirement pension. Also, a higher symptomatology (guilt and sense of presence) is obviously expected within people who are still dealing with the mourning process. On the other hand, grievers with some knowledge about the grieving process are able to understand their feelings (just as these are expected in a mourning process), and so, to block sense of presence, feeling safer and avoiding complications.

With respect to a child death, it can be considered by parents as a role failure (Alameda \& Barbero, 2009), feeling they have failed in their responsibility of taking care and pro-

\section{References}

Abad, F. J., Olea J., Ponsoda V., \& García C. (2011). Medición en ciencias sociales y de la salud [Measuring health and social sciences]. Madrid: Editorial Síntesis.

Alameda, A., \& Barbero, J (2009). El duelo en padres del niño oncológico [Grief in cancer boy's parents]. Psicooncología, 6(2-3); 485-498.

Barreto, P., de la Torre, O., \& Pérez-Marín, M. (2012). Detección de Duelo Complicado [Screening of Complicated Grieg]. Psicooncología, 9(2-3), 353-368. https://doi.org/ 10.5209/rev_PSIC.2013.v9.n2-3.40902

Barreto, P., Yi, P., \& Soler, C. (2008). Predictores de duelo complicado [Complicated grief predictors]. Psicooncología, 5(2), 383-400.

Bentler, P. M. (1992). EQS Structural Equations Program Manual. Los Angeles, CA: BMDP Statistical Software

Bermejo, J.C. \& Santamaría, C. (2011). El duelo, luces en la oscuridad [The mourning, lights in the dark]. Madrid: La Esfera de los Libros, S.L

Bermejo, J.C., Magaña, M. \& Villacieros, M. (2016). Las cinco pulgas del duelo [The five fleas of grief]. Madrid: PPC

Bermejo, J.C., Magaña, M., Villacieros, M., \& Rodil, V. (2017). Design and validation of the Inventory of Life Factors Interfering Grief and Complicated Grief (Oral communication). The $11^{\text {th }}$ International Conference on Grief and tecting their child. And, on the other hand, it is an unexpected death (García-Viniegras \& Pérez-Cernuda, 2013). Higher sexuality scores in parents make sense, as it may be difficult for them to have intimate relations when there has been a major loss. Thus, in the event of child death, both guilt and sexuality are the most disturbing "fleas" interfering with the parent's grieving process. Focusing primarily in relieving the effects of both disturbances may be of great help to the grievers.

As for the limitations within this study, we could consider the fact that sex participants disproportion may have prevented the ILFIGv2 from detecting differences previously described by other authors (Bierhals et al., 1995; Steele, 1992; Versalle \& McDowell, 2005). In addition, the variable used as an external criterion is based on the assumption that the more experience of mourning, the greater awareness of difficulty in its elaboration, which may not always be the case. Notwithstanding this issue just mentioned, results shown for CFA and external criteria associations, as well as reliability through internal consistency analysis, demonstrate ILFIGv2 as a valid and reliable complicated grief risk factor brief measurement. In addition, the ILFIGv2 questionnaire can be responded at any time after the loss of a beloved one, as no significant differences were found within the variable time from death.

We can therefore draw this research to a close indicating that there are several circumstances around death that can actually complicate the normal mourning process and lengthen it. Also, this second version of the Inventory of Life Factors Interfering Grief and Complicated Grief provides a model and a measurement instrument of several life circumstances (Guilt, Inheritance, Economy, Sexuality, Immortality and Sense of presence) that can interfere with grief. What is more, when taken into account, it heralds a potential means to prevent and avoid it, as there are very often many unexpressed aspects which, according to grievers, demand attention.

Bereavement in Contemporary Society. Program Abstract Book. Lisbon (July, 12-15)

Bierhals, A. J., Prigerson, H. G., Fasiczka, A., Frank, E., Miller, M., \& Reynolds, C. F. (1995). Gender differences in complicated grief among the elderly. Omega: Journal of Death and Dying, 32(4), 303-317. https://doi.org/10.2190/437W-EDWJ-LMQL-0CB9

Brown, T. A. (2006). Confirmatory factor analysis for applied research. New York, NY: The Guilford Press.

Burke, L. A., \& Neimeyer, R. A. (2012). Prospective Risk Factors for Complicated Grief. In M.S. Stroebe, H. Schut, J. van der Bout \& P. Boelen (Eds.), Complicated Grief: Scientific foundations for healthcare professionals (145161). New York, NY: Routledge/Taylor \& Francis Group

Echeburúa, E., \& Herrán, A. (2007). ¿Cuándo el duelo es patológico y cómo hay que tratarlo? [When is grief pathological and how should it be treated?] Análisis y Modificación de Conducta, 33(147), 31-50

Field, N.P., \& Filanosky, C. (2009). Continuing Bonds, Risk Factors for Complicated Grief, and Adjustment to Bereavement. Death Studies, 34(1), 1-29. https://doi.org/10.1080/07481180903372269 
García-Viniegras, C. R. V., \& Pérez-Cernuda, C. (2013). Duelo ante muerte por suicidio [Mourning to death by suicide]. Revista Habanera de Ciencias Médicas, 12(2), 265-274.

Hu L., \& Bentler P. M. (1998). Fit indices in covariance structure modeling: Sensitivity to underparameterized model misspecification. Psychological Methods, 3, 424-453. https://doi.org/10.1037/1082-989X.3.4.424

Magaña, M., \& Bermejo, J.C. (2013). "Modelo Humanizar" de intervención en duelo. ["Humanize Model" for intervention in bereavement processes]. Santander: Sal Terrae

Muthén L. K., \& Muthén B. O. (1998-2012). Mplus user's guide. Seventh Edition. Los Ángeles, CA: Muthén \& Muthén.

Pardo, A., Ruiz, M. A. \& San Martin, R. (2009). Análisis de datos en ciencias sociales y de la salud I. [Data analyses in social and health sciences I] Madrid: Síntesis
Parkes, C.M., \& Weiss, R.S. (1983). Recovery from bereavement. New York:Basic Books

Steele, L. (1992) Risk factor profile for bereaved spouses. Death Studies, 16(5), 387-399, https://doi.org/10.1080/07481189208252587

Versalle, A., \& McDowell, E. E. (2005). The Attitudes of Men and Women concerning Gender Differences in Grief. OMEGA - Journal of Death and Dying, 50(1), 53-67. https://doi.org/10.2190/R2TJ-6M4F-RHGDC2MD

Worden, J. W., Aparicio, Á., \& Barberán, G. S. (1997). El tratamiento del duelo: asesoramiento psicológico y terapia [Bereavement treatment: counseling and therapy]. Barcelona: Paidós. 